\title{
A mouse is not a rat is not a man: species-specific metabolic responses to sepsis - a nail in the coffin of murine models for critical care research?
}

\author{
Peter Radermacher ${ }^{1 *}$ and Philippe Haouzi ${ }^{2}$
}

\author{
* Correspondence: \\ peter.radermacher@uni-ulm.de \\ ${ }^{1}$ Sektion Anästhesiologische \\ Pathophysiologie und \\ Verfahrensentwicklung, Klink für \\ Anästhesiologie, \\ Universitätsklinikum, \\ Helmholtzstrasse 8-1, D-89081 Ulm \\ Germany \\ Full list of author information is \\ available at the end of the article
}

\author{
"All models are wrong, but some are useful." \\ -Box GEP, Draper NR (1987) Empirical model-building and response surface, Wiley
}

Sepsis and consequent multi-organ failure are the leading causes of mortality in critically ill patients. Numerous therapeutic strategies, which yielded promising results in preclinical studies, have failed to show any efficacy in clinical trials. Historically, most of our (patho)physiological understanding of cardiovascular regulation in health and disease has been established in larger mammals, e.g., dog, pig, and sheep. However, a very large body of the literature collected over recent decades originates from investigations in rodents. Despite their small size, which makes surgery difficult and limits repetitive blood sampling, murine models have been widely used, not because they are more faithful to adult human pathophysiology than larger mammals but because they are inexpensive, easy to handle and care for, and with availability of gene knockout and overexpression strains. Investigators have performed studies without necessarily having a good appreciation of some fundamental differences in the physiology of rodents. These have been long established by comparative physiologists, yet have never been taught in any medical school. One can query the logic of inferring information on mechanisms involved in septic shock using species capable of decreasing their high resting metabolic rate both rapidly and massively, and with the associated circulatory and respiratory responses.

Mouse models of acute inflammatory disorders have recently been questioned by Seok et al. [1] who found that "genomic responses to different acute inflammatory stresses are highly similar in humans", whereas "these responses are not reproduced in current mouse models". In this context, Zolfaghari et al. [2] compared the metabolic responses to polymicrobial sepsis in rats and mice. Their main findings were that mice presented with a progressive drop in whole body $\mathrm{O}_{2}$ uptake and a concurrent fall in body temperature, which was only partially restored by external warming. This marked metabolic depression coincided with pronounced impairment of left heart systolic contractility. In sharp contrast, only severely ill rats showed a comparably decreased cardiac output, and the metabolic depression was only present during the late premortem period.

How can we explain these findings by Zolfaghari et al. [2]? The authors have the merit of raising an issue of crucial importance for critical care research, i.e., whether or 
not murine models can yield sufficient information to enable a good design of clinical studies. In particular, they must be commended for having achieved not only an identical 72-h mortality but also comparable 24-h clinical severity scores. This is by no means trivial in the two species investigated: body weight differs by an order of magnitude, and mice present with a twofold to threefold higher metabolic expenditure on a per gram basis. Interestingly, albeit the final outcome was identical, the time course of the clinical development of sepsis differed: the clinical severity score was already higher in mice with "severe" sepsis at $6 \mathrm{~h}$ post inoculation of feces, whereas in rats, this difference was only apparent at $24 \mathrm{~h}$. One might argue that the resuscitation technique may have assumed importance in this context: rats were infused with continuous i.v. fluids via a jugular venous catheter inserted prior to the experiment, while mice received intermittent s.c. bolus administration. Moreover, even sham-operated mice showed moderate hyperlactatemia, hyperglycemia, and hyperchloremia, and, in particular, marked metabolic acidosis. The latter is a common finding in mouse models reported by other authors $[3,4]$, even when balanced electrolyte solutions rather than saline were used as maintenance fluids $[5,6]$. This prompted some authors to systemically administer bicarbonate infusions [7].

The authors' observation of markedly reduced energy expenditure and consecutive hypothermia in mice is not new and is most likely due to the fundamentally different metabolic response in this species rather than to any of the abovementioned phenomena: in response to tissue hypoxia, mice reduce their energy expenditure by decreasing "nonshivering thermogenesis". Nonshivering thermogenesis [8] as a result of the high activity of mitochondrial uncoupling proteins [9] represents a very large proportion of overall $\mathrm{O}_{2}$ consumption which can therefore be depressed very rapidly without affecting ATP production. Such a regulation of metabolism represents a unique protective adaptation, observable in many species including human babies. Reduced $\mathrm{VO}_{2}$ can be observed during hemorrhagic shock or severe hypoxia in rats [10], but this response is less pronounced in adult individuals [11,12]. In other words, even "small animal model species are not created equal" [13]. Hence, whenever interventions target or affect cellular energy metabolism [14,15], results obtained in mouse models may be misleading. In keeping with their thermal and metabolic regulation, the physiology of an adult mouse is much closer to that of a premature newborn baby than an adult rat!

Consequently, should we abandon mouse models for critical care research and replace them with rats? Undoubtedly, rats are easier to handle than mice, and they have a 10 to 20 times higher blood volume. However, in rats, the response to injury may also markedly differ from that of humans, in particular with respect to mediators that are referred to assume crucial importance during sepsis. For example, rats present with blood concentrations of nitric oxide (NO) metabolites that are 10 to 20 times higher than those in humans. Moreover, they are particularly resistant to oxidative stress, a common phenomenon during sepsis, due to their high tissue activity of antioxidant enzymes [16,17]. Indeed, there is an abundant literature on promising rat studies of antioxidants or NO inhibitors, which have never translated into clinical practice. However, this problem is inherent to the use of other "nonhuman" models; mice, for instance, also show different activity for inducible NO synthase (iNOS)-related NO release $[18,19]$. As a consequence, one might consider only using large animal species, e.g., swine, dogs, or ewes. However, in addition to cost, labor, and specific 
ethical concerns of the lay public, there is no ideal large animal species either which fits all needs: The use of ruminants may be questioned when gastrointestinal function is to be investigated due to their different anatomy. Despite their general similarity with humans, swine can be a problem when they are used in targeting lung mechanics and perfusion due to a lack of collateral alveolar ventilation and a marked pulmonary hypertensive response.

Finally, due to their experimental design covering several days, Zolfaghari et al. [2] could not address the question whether it is necessary - and if so, to what extent - to integrate standard intensive care procedures into an experimental design, ultimately to guarantee clinical relevance for critical care research. The rationale for this discussion is self-evident and was highlighted by the late Prof. Daniel Traber more than a decade ago, "Would you...accept data on a septic patient who was not resuscitated..., ...who did not even have blood pressures and heart rates monitored?" [20]. This point is essential since although murine models are very different from humans due to their own evolutionary specificities, when it comes to shock or its treatment, the persistence of fundamental responses shared by all mammals must be acknowledged. For instance, striking similarities exist between all species as well as through the different ages (from premature babies to elderly patients) as far as the principles of treatment of septic shock (antibiotics, volume replacement, etc....) are concerned. Although the time course of the clinical development of sepsis differed between rats and mice, in the study of Zolfaghari et al. [2], the final outcome was identical in both species. Whenever standard ICU strategies are used [21,22], the similarities between models become even more obvious, regardless of differences in physiological regulation, level of inflammation, temperature, and $\mathrm{VO}_{2}$ or $\mathrm{NO}$ regulation. For instance, as demonstrated by Hollenberg [22], the mortality of mice $48 \mathrm{~h}$ after cecal ligation and puncture was close to $100 \%$ without resuscitation, whereas fluids and antibiotic therapy resulted in $45 \%$ survival, a value close to the clinical setting. For obvious technical reasons, the smaller the species studied, the more challenging the intensive care-type measurements during an experiment are. Consequently, this problem is much more pronounced in murine than in rat models. The use (or lack) of mechanical ventilation or hemodynamic monitoring is a prominent example. The miniaturization of equipment will certainly allow many limitations to be overcome, but will of course not solve fundamental species-specific differences. Although it would be interesting to develop methods to reduce basal metabolic rate in humans based on the response seen a mouse model, relevant qualitative as well as semiquantitative information on the benefits of therapeutic strategies could still be obtained using small mammals. Similar to the vast majority of researchers, Zolfaghari et al. [2] used young, male, and otherwise healthy animals. These certainly do not represent the majority of ICU patients who are often elderly with chronic preexisting comorbidities. Age, gender, and comorbidities influence outcomes not only in patients but also in experimental models of sepsis [23-32].

Hence, as a bottom line conclusion, Zolfaghari et al. [2] highlighted an important issue of translational research in critical care medicine, i.e., that data on the physiological response to septic shock in a mouse or a rat model can only be understood in keeping with the frame of reference of the animal's physiology. Such data cannot be directly extrapolated to septic patients. The hope is that by acknowledging and understanding these differences, the resources involved with murine models will not be wasted and that rodents 
could be continued to be used, with a rational frame of reference based on objective elements of comparative pathophysiology - rather than physiology - a discipline which is still in its very early age and which remains to be developed. Only then could mouse models take their real place in critical care research along with large animal investigations and in vitro (i.e., reductionist) approaches before commencement of any clinical trial.

Competing interests

Both authors declare that they have no competing interests.

\section{Authors' contributions}

PR and PH drafted the manuscript, read, and approved the final version.

\section{Acknowledgements}

This publication is supported by the Klinische Forschergruppe 200 (KFO 200) "Die Entzündungsantwort nach Muskulo-Skeletalem Trauma" (Deutsche Forschungsgemeinschaft Ra 396/9-2).

\section{Author details}

${ }^{1}$ Sektion Anästhesiologische Pathophysiologie und Verfahrensentwicklung, Klink für Anästhesiologie, Universitätsklinikum, Helmholtzstrasse 8-1, D-89081 Ulm, Germany. ${ }^{2}$ Division of Pulmonary and Critical Care Medicine, Penn State University College of Medicine, Penn State Hershey Medical Center, Hershey, PA 17033, USA.

Received: 9 October 2013 Accepted: 10 October 2013

Published: 29 October 2013

\section{References}

1. Seok J, Warren HS, Cuenca AG, Mindrinos MN, Baker HV, Xu W, Richards DR, McDonald-Smith GP, Gao H, Hennessy L, Finnerty CC, López CM, Honari S, Moore EE, Minei JP, Cuschieri J, Bankey PE, Johnson JL, Sperry J, Nathens AB, Billiar TR, West MA, Jeschke MG, Klein MB, Gamelli RL, Gibran NS, Brownstein BH, Miller-Graziano C, Calvano SE, Mason PH, et al. (2013) Genomic responses in mouse models poorly mimic human inflammatory diseases. Proc Natl Acad Sci USA 110:3507-3512

2. Zolfaghari PS, Pinto BB, Dyson A, Singer M (2013) The metabolic phenotype of rodent sepsis: cause for concern? Intensive Care Med Exp. in press

3. Volpato GP, Searles R, Yu B, Scherrer-Crosbie M, Bloch KD, Ichinose F, Zapol WM (2008) Inhaled hydrogen sulfide: a rapidly reversible inhibitor of cardiac and metabolic function in the mouse. Anesthesiology 108:659-668

4. Reiss LK, Kowallik A, Uhlig S (2011) Recurrent recruitment manoeuvres improve lung mechanics and minimize lung injury during mechanical ventilation of healthy mice. PLoS One 6:e24527

5. Wagner F, Scheuerle A, Weber S, Stahl B, McCook O, Knöferl MW, Huber-Lang M, Seitz DH, Thomas J, Asfar P, Szabó C, Möller P, Gebhard F, Georgieff M, Calzia E, Radermacher P, Wagner K (2011) Cardiopulmonary, histologic, and inflammatory effects of intravenous $\mathrm{Na}_{2} \mathrm{~S}$ after blunt chest trauma-induced lung contusion in mice. J Trauma 71:1659-1667

6. Wagner F, Wagner K, Weber S, Stahl B, Knöferl MW, Huber-Lang M, Seitz DH, Asfar P, Calzia E, Senftleben U, Gebhard F, Georgieff M, Radermacher P, Hysa V (2011) Inflammatory effects of hypothermia and inhaled $\mathrm{H}_{2} \mathrm{~S}$ during resuscitated, hyperdynamic murine septic shock. Shock 35:396-402

7. Wolthuis EK, Vlaar AP, Choi G, Roelofs JJ, Juffermans NP, Schultz MJ (2009) Mechanical ventilation using noninjurious ventilation settings causes lung injury in the absence of pre-existing lung injury in healthy mice. Crit Care 13:R1

8. Mortola JP (1993) Hypoxic hypometabolism in mammals. News Physiol Sci 8:79-82

9. van Marken Lichtenbelt WD, Schrauwen P (2011) Implications of non-shivering thermogenesis for energy balance regulation in humans. Am J Physiol Regul Integr Comp Physiol 301:R285-R296

10. Haouzi P, Van de Louw A (2013) Uncoupling mitochondrial activity maintains body $\mathrm{VO}_{2}$ during hemorrhageinduced $\mathrm{O}_{2}$ deficit in the anesthetized rat. Respir Physiol Neurobiol 186:87-94

11. Frappell P, Lanthier C, Baudinette RV, Mortola JP (1992) Metabolism and ventilation in acute hypoxia: a comparative analysis in small mammalian species. Am J Physiol 262:R1040-R1046

12. Haouzi P, Bell HJ, Notet V, Bihain B (2009) Comparison of the metabolic and ventilatory response to hypoxia and $\mathrm{H}_{2} \mathrm{~S}$ in unsedated mice and rats. Respir Physiol Neurobiol 167:316-322

13. Dobson GP (2012) Small animal model species are not created equal. Crit Care Med 40:711

14. Haouzi P (2011) Murine models in critical care research. Crit Care Med 39:2290-2293

15. Wagner K, Calzia E, Georgieff M, Radermacher P, Wagner F (2011) A mouse is not a man: should we abandon murine models in critical care research? Crit Care Med 39:2371-2373

16. Godin DV, Garnett ME (1992) Species-related variations in tissue antioxidant status-I. Differences in antioxidant enzyme profiles. Comp Biochem Physiol B 103:737-742

17. Godin DV, Garnett ME (1992) Species-related variations in tissue antioxidant status—II. Differences in susceptibility to oxidative challenge. Comp Biochem Physiol B 103:743-748

18. Reade MC, Young JD (2003) Of mice and men (and rats): implications of species and stimulus differences for the interpretation of studies of nitric oxide in sepsis. Br J Anaesth 90:115-118

19. Bauer M, Reinhart K (2006) From mice and MOF: rodent models, immune modulation, and outcome in the critically ill. Crit Care Med 43:912-923 
20. Traber DL (1999) Expired nitric oxide and shock in high order species. Crit Care Med 27:255-256

21. Fink MP, Heard SO (1990) Laboratory models of sepsis and septic shock. J Surg Res 49:186-196

22. Hollenberg SM (2005) Mouse models of resuscitated shock. Shock 24(Suppl 1):58-63

23. Khan Al, Coldewey SM, Patel NS, Rogazzo M, Collino M, Yaqoob MM, Radermacher P, Kapoor A, Thiemermann C (2013) Erythropoietin attenuates cardiac dysfunction in experimental sepsis in mice via activation of the $\beta$ common receptor. Dis Model Mech 6:1021-1030

24. Drechsler S, Weixelbaumer K, Raeven P, Jafarmadar M, Khadem A, van Griensven M, Bahrami S, Osuchowski MF (2012) Relationship between age/gender-induced survival changes and the magnitude of inflammatory activation and organ dysfunction in post-traumatic sepsis. PLoS One 7:e51457

25. Kaplan JM, Nowell M, Lahni P, O'Connor MP, Hake PW, Zingarelli B (2012) Short-term high fat feeding increases organ injury and mortality after polymicrobial sepsis. Obesity 20:1995-2002

26. Osuchowski MF, Craciun FL, Schuller E, Sima C, Gyurko R, Remick DG (2010) Untreated type 1 diabetes increases sepsis-induced mortality without inducing a prelethal cytokine response. Shock 34:369-376

27. Turnbull IR, Clark AT, Stromberg PE, Dixon DJ, Wollsey CA, Davis CG, Hotchkiss RS, Buchman TG, Coopersmith CM (2009) Effects of aging on the immunopathologic response to sepsis. Crit Care Med 37:1018-1023

28. Singer G, Stokes KY, Terao S, Granger DN (2009) Sepsis-induced intestinal microvascular and inflammatory responses in obese mice. Shock 31:275-279

29. Strandberg L, Verdrengh M, Enge M, Andersson N, Amu S, Önnheim K, Benrick A, Brisslert M, Bylund J, Bokarewa M, Nilsson S, Jansson JO (2009) Mice chronically fed high-fat diet have increased mortality and disturbed immune response in sepsis. PLoS One 4:e7605

30. Miyaji T, Hu X, Yuen PST, Muramatsu Y, lyer S, Hewitt SM, Star RA (2003) Ethyl pyruvate decreases sepsis-induced acute renal failure and multiple organ damage in aged mice. Kidney Int 64:1620-1631

31. Saito H, Sherwood ER, Varma TK, Evers BM (2003) Effects of aging on mortality, hypothermia, and cytokine induction in mice with endotoxemia or sepsis. Mech Ageing Dev 124:1047-1058

32. Turnbull IR, WIzorek JJ, Osborne D, Hotchkiss RS, Coopersmith CM, Buchman TG (2003) Effects of age on mortality and antibiotic efficacy in cecal ligation and puncture. Shock 19:310-313

doi:10.1186/2197-425X-1-7

Cite this article as: Radermacher and Haouzi: A mouse is not a rat is not a man: species-specific metabolic responses to sepsis - a nail in the coffin of murine models for critical care research? Journal of Software Engineering Research and Development 2013 1:7.

\section{Submit your manuscript to a SpringerOpen ${ }^{\circ}$ journal and benefit from:}

- Convenient online submission

- Rigorous peer review

- Immediate publication on acceptance

- Open access: articles freely available online

- High visibility within the field

- Retaining the copyright to your article 